\title{
The Affect of E-commerce on the Tertiary Industry
}

\author{
Guo Xiwei \\ School of Economic and Management \\ Shengyang Aerospace University \\ Shengyang, China \\ Guo Xiwei@sau.edu.cn
}

\begin{abstract}
Currently, China is still in the process of industrial restructuring. The steady development of economy is the basic condition that tertiary industry required. The tertiary industry, especially the development of producer services plays a decisive role in supporting the manufacturing industry's innovation and upgrade. By virtue of lower cost and effective, e-commerce is not only popular among ordinary consumers, but also enable the small and middle-sized enterprises to search business opportunities, take market share and develop itself, which has become the important power of China to turn its development modes and optimize the industrial structure.
\end{abstract}

Keywords-e-commerce, tertiary industry, affect, countermeasures 1

\section{INTRODUCTION}

As the development of media forms, e-commerce has presented the great convergence and generated many innovative forms. In the e-commerce macro-environment, how to adapt to the optimizing and upgrading of tertiary industry and during which the opportunities and challenges we faced, both of them should be considered and worthy of intensive study.

By right of the e-commerce platform, use the capability of independent innovation to improve the industrial technology level, regard the strengthening of the capability of independent innovation as the key link of readjusting industrial structure, establish a market-oriented technology innovation system with enterprise as the main body and industry-university-research cooperation, greatly improve the original innovation ability, integrated innovation ability, digestive absorption and re-innovation ability, as well as upgrade the overall industrial technology level. Quicken the development of e-commerce to help upgrading and optimization as well as structural adjustment of China's tertiary industry.

China's tertiary industry includes two large sectors, circulation and service, dividing into four grades:

The first grade is the circulation sector: transportation, post and telecommunications, catering business, material supply and marketing and warehousing;

The second grade is the life service sector: finance, insurance, geological survey, real estate management, public utility, resident services, tourism, information consulting service and various technology services;

The third grade is the sector that improves the scientific and cultural level and resident quality service: education, culture, broadcast, television, scientific research, health, sports, as well as social and welfare services.

The forth grade is state organs, political parties, social organizations, police, army etc., not included in the output value of tertiary industry and the gross national product of China. So, in general speaking, this tertiary industry is a service industry.

\section{OPPORTUNITIES AND CHALLENGES BROUGHT BY E- COMMERCE}

\section{A. Opportunities Brought by E-ecommerce}

Taken as a whole, China's e-commerce began form 1998 and developed actually from 2004. As the continuous improvement of internet technology, the development of national economy and the constantly improvement of the living standard of residents, the development of ecommerce has brought about opportunities for China's tertiary industry.

\section{1) Profitable diversification}

As the development of science and the progress of social concept, the people's ability to understand and accept new things is increasingly strong and can capture business opportunities more and more accurately. The generation, rise and current popularization of e-commerce, made lots of tertiary industries to focus on this platform and began to use the internet to re-explore profitable diversification. Whether the aim of macro-industry restructuring, or various individual microenterprises, the ultimate aim is to spur the economic development and achieve the great rejuvenation of the Chinese nation.

Tertiary industry began to use e-commerce platform and integrate online business with offline business to open the $\mathrm{O} 2 \mathrm{O}$ business model, in which was not do business in a single physical store and offer people-oriented services simply, but open an online store and enter the group buying platform. This model expanded distribution channels and brought more opportunities to promote its products and services, thus increasing the profitable diversification and possibility.

From the consumption of necessity in daily life to the real services offered by a physical store, the e-commerce platform provided more profitable opportunities for tertiary industry. Behind the fierce competition of the ecommerce giants in recent years, a great many tertiary industries are the winners. From several years of the hottest"Double-11"activities to the emerging of various 
group buying websites, e-commerce application brought about infinite business opportunities for tertiary industry.

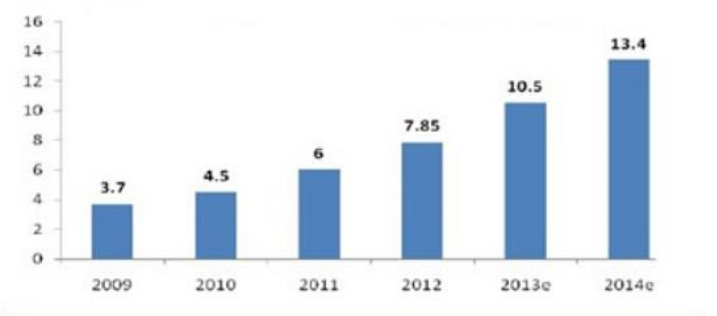

Figure 1. Transaction size of China's e-commerce market (trillion Yuan) in 2009-2014

\section{2) Operation cost reduction}

The analysis of the current development status of tertiary industry shows that, under the background of fierce competition and resource's increasingly shortage, the survival pressure on tertiary industry is increasing continuously, with more and more operation cost because consumers' diligently pursuing to service quality. In this case, using e-commerce platform can reduce the operation cost sufficiently, so as to lessen enterprise's pressure.

\section{3) Promoting industrial reform}

In the rapidly developing human society, machineparsable things are unable to adapt to the social context that develops continuously, neither does the industrial structure. Among the definite opportunities brought by ecommerce, only the industry that constantly breaks through itself, renews concepts and reforms timely, can survive in the current development trend. Internet's efficiency, convenience and integrating with tertiary industry, stand for the great reform on the management concepts, promotion methods and profit models of traditional industries, which further enhance the strong stimulation to economy. E-commerce provided important opportunities for the rationalization and upgrading and optimization of tertiary industry during critical periods of economic restructure.

\section{B. Challenges Brought by E-ecommerce}

Among the challenges brought by e-ecommerce, the most visually one is the impact on physical stores. People spent more energy and financial resources on the transactions on internet. From the impact from online store's lower prices on physical stores' products to the sharp attack from the internet finance products, the important business of traditional banks, deposit, suffered a huge blow. We can feel about the affect of e-commerce on tertiary industry through things like this.

In recent years, e-commerce has already become a pronoun stands for economic development model in the future insensibly. As a commercial activity process, ecommerce developed rapidly with a profound affect on human society progress and prosperity, and will bring about an unprecedented reform. The affect of e-commerce on social economy was far more than the commerce itself.

\section{PROBLEMS OF TERTIARY INDUSTRY IN E- COMMERCE ENVIRONMENT}

\section{A. Poor adaptability to e-commerce environment}

For the current development status of China's tertiary industry, tertiary industry can't adapt well to the ecommerce environment that matures increasingly, which uses the e-commerce platform with low degree of opening and being geared to international standards, causing the weak international competitiveness.

\section{B. Professional shortage}

The "internet comprehensive talents" having various knowledge and skills, including their own professional knowledge, website information technology, marketing etc., will become the most in demand talents for all the time in the future. The demand of quality internet talents had entered a period of rapid growth. Up to October, 2013, the demand of quality internet talents increased more than $55 \%$ when compared with the same period of last year. These posts include internet customer service managers, product managers, product technology R\&D personnel etc. All services provided by organizations of the traditional tertiary industry involve the intervention by internet industry product managers and internet researchers. Both had played a pivotal role in enterprises' business development.

\begin{tabular}{|c|c|c|c|}
\hline \multicolumn{4}{|c|}{ Top ten knowledge and skills for e-commerce talents } \\
\hline Top 1 & $\begin{array}{l}\text { Information } \\
\text { resource } \\
\text { management }\end{array}$ & Top 6 & Marketing \\
\hline Top 2 & $\begin{array}{c}\text { Strategic } \\
\text { management of } \\
\text { enterprise }\end{array}$ & Top 7 & Network marketing \\
\hline Top 3 & $\begin{array}{l}\text { Customer } \\
\text { relationship } \\
\text { management }\end{array}$ & Top 8 & $\begin{array}{c}\text { Project } \\
\text { management }\end{array}$ \\
\hline Top 4 & Project planning & Top 9 & E-payment \\
\hline Top 5 & $\begin{array}{c}\text { Capital operation } \\
\text { management }\end{array}$ & Top 10 & $\begin{array}{l}\text { Standardization } \\
\text { management }\end{array}$ \\
\hline
\end{tabular}

Figure 2. Top ten knowledge and skills for e-commerce talents

\section{Unsound relevant policies}

In the present e-commerce macro-environment, China's tertiary industry is faced with various problems, such as decentralized overall market size, excessively decentralized funds, poor infrastructure construction, unsound laws and regulations, incomplete relevant policies, etc. Also, for tertiary industry, barriers to enter in the ecommerce business are high; government regulation is poor; and can't take the market direction correctly.

At present, the e-commerce regulation establishment is relatively lagging behind; market access service regulatory system, credit system, statistics monitoring system, industrial investment and financing system etc., are urgent to be set up; the credible, secure and convenient website shopping environment the consumers need is still not incomplete, thus it is a severe trial for e-commerce. 


\section{Security of instruments of payment}

Similarly, the payment security is the biggest concerns for both transaction parties.

Facing the fierce attack from internet baby legion and mobile terminal payment, Central bank claimed to terminate the payment transactions and products in March 2014, such as two-dimension code payment, virtual credit cards, etc., and said that such payment products are need to be improved. During the spring festival, telecommunication frauds and two-dimensional code frauds, etc. are disclosed frequently, showing that everyone should pay attention to the security of instruments of payment and enhance individual risk awareness.

\section{COUNTERMEASURES FOR TERTIARY INDUSTRY TO SOLVE PROBLEMS}

\section{A. Opportunities grasp, bold innovation}

In the first quarter of this year, China's tertiary industry increased by $7.8 \%$ compared with the same period of last year; increment speed was $0.5 \%$ higher than that of secondary industry; while the value added of tertiary industry accounted for $49 \%$ of GDP, gone up by 1.1 percentage points compared with the same period of last year. All these data clearly showed that the rapid development of tertiary industry and its development prospect couldn't be ignored, which was playing a great role in stimulating China's economic growth.

\section{B. Macroscopic planning, development guidance}

China's economic structural adjustment has obtained active progress, with quickened step of industrial upgrading and optimization. According to the economic data released by the National Bureau of Statistics, China's value added of tertiary industry accounted for 49\% of GDP, increased by 1.1 percentage points compared with the same period of last year. In the e-commerce macroenvironment, use the e-commerce's universality to improve people's livelihood and integrate e-commerce with very aspect of common people' life, allowing citizens to enjoy the benefits and convenience provided by ecommerce actually.

1) Respect quickening tertiary industry development as the strategic emphasis of economic growth

The bottleneck of the transformation of China's economic development modes and industrial structure upgrading lies in the poor tertiary industry. Henceforth, should strengthen the overall planning and guidance, and improve the orderly, healthy and coordinated development of tertiary industry through innovation to adapt to the development trend of tertiary industry that uses globalization as main driving force, enlarge the convergence with e-commerce as well as strive to break through the bottleneck, as well as transform tertiary industry's open leaping upgrading into one of the main attack directions of development mode transformation and the achievement of strategic restructuring of the economy. Grasp the opportunities provided by the e-commerce macro-environment firmly to realize the strategic transformation, allowing e-commerce becoming the main driving force for tertiary industry.
2) Multiple channels solutions for increasing funding, strengthening future development potential of modern tertiary industry

In the investment direction, should gradually increase the investment on tertiary industry, and change the relatively poor state of China's tertiary industry by adjusting investment direction to establish a more reasonable structure for the three main industries. Meanwhile, should further loosen the industry regulation, lower industry entry barriers and strengthen services to allow very service industries to develop properly on the basis of sufficient competition, and support the small and middle-sized enterprises in tax, technologies, credit, etc.

\section{Vigorous advocacy, talent cultivation}

\section{1) Give e-commerce a definite positioning}

The characteristics of e-commerce determines that the knowledge the e-commerce talents have should be advanced and complex, which does not mean that it is combined and piled lots of technologies and commercial knowledge in any way you like.

\section{2) Do e-commerce practical training flexibly}

Also, should do the design of enterprise's network marketing promotion plan and implementation plans of enterprise e-commerce, etc., enabling the e-commerce talents to finish the course study and operation, obtain some benefits and enhance the practical skills while complete the actual projects.

E-commerce should follow closely with the modern steps and market demands to practice boldly and experience personally the charm of internet and ecommerce.

\section{Step by step, constantly improvement}

In order to further sweep away the barriers blocking ecommerce platform for rapidly developing tertiary industry, should begin with relaxing the control over market entry macroscopically, simplifying procedures for approval, lowering enter barriers, improving the relevant strategic as well as laws and regulations, etc., and require the relevant department to formulate supporting measures quickly, to establish a good e-commerce development environment for tertiary industry.

Also, establish the logistics and public information platform and cargo distribution center, quicken standardized facility application and drive the linkage development between third-party logistics and manufacturing industry.

\section{E. Establish e-commerce demonstration base}

By establishing e-commerce demonstration bases across China, such as Shenyang approved as an ecommerce demonstration city, thus e-business supportive policies will be released soon and Shenyang became the biggest city with the most website shopping groups and the maximum e-commerce transaction volume in northeast China.

Shenyang city was officially approved to establish as a national e-commerce demonstration city, next, "One base, three centers", i.e., Hunnan National E-Commerce Demonstration Base, Northeast China E-commerce Research and Innovation Center, Logistic and Distribution Center, Operation and Settlement Center, etc. will be 
constructed to drive the development of e-commerce in agriculture, manufacturing industry and service industry.

\section{RESULT OF E-COMMERCE CONCLUSION WITH RESPECT TO TERTIARY INDUSTRY}

This article analyses sufficiently the affect of ecommerce development on tertiary industry through the research on tertiary industry's growing. China's industrial structure has been adjusted and optimized constantly since the opening up and reform policy was adopted 30 years ago. The statistics shows that, the annual average of value added of China's tertiary industry had increased by $10.8 \%$ from 1979 to 2012, higher than 1 percentage point compared with the same period of last year. With China's industrialization stepping from middle period toward latter period, the overall increment speed of secondary industry, represented by manufacturing industry, kept slowing, while tertiary industry developing more and more quickly. Both the total output of tertiary industry and its share in GDP exceed those of secondary industry in China in 2013. In the first quarter of this year, the value added of tertiary industry accounted for $49 \%$ of GDP, with increment speed of 0.5 percentage point higher than that of secondary industry.

Currently, China is still in the course of industrialization, tertiary industry, especially the producer service development plays a decisive role in supporting the innovation and upgrading of manufacturing industry. Should depend more on market mechanism and innovation drive to quicken the integration into e-commerce macroenvironment, use sufficiently the vast e-commerce platform to quicken the upgrading and optimization of industrial structure, as well as improve the overall quality and completeness of national economy. The affect of ecommerce on the tertiary industry is both positive and negative. Only sufficient analysis, bold concept transform and seizing the opportunities brought by e-commerce macro-environment, could use the e-commerce platform to perform transformation for tertiary industry and attain better development.

\section{CONCLUSION}

Use internet thought to do e-business. Using internet thought to do e-business, is almost the common view of ecommerce development. This article believes that the internet core can be generalized by seven words, "concentration, peak, public assessment and quickness". Internet should never be used only as a tool. If said that the past e-business used IT only for trade, enterprises, especially the traditional industry use internet to transact, which is the real spring for e-business. It is not a single mode for tertiary industry to develop internet e-business, but integrating the recourses of decentralized labors, found, ideas, etc as much as possible. Nowadays, do innovations on oneself completely is nothing but being challenged and attacked by others. Actually speaking, e-business can also use the "barrel principle"; a barrel can take how much water, which is not decided by the longest board. The upgrading and optimization of tertiary industry structure can use e-business to demonstrate the actual purpose of internet, which will formulate a complex and interlocking ecosystem eventually.

\section{REFERENCES}

[1] Li Jiangfan. Views of the Strategic Position and Development Direction of China's Tertiary Industry [J]. Economics of Finance and Trade, 2014(1) : 90-93.

[2] Lin Mingshu, Han Runer. Causes of Lagging Development in Tertiary Industry and Structural Adjustment [J]. Journal of Xiamen University, 2014, 6(8):6-7.

[3] Wang Gang. The Affect of E-commerce on the Structure of Tertiary Industry [J]. Journal of Journal of Jiangxi Finance College, 2012, 23(7): 45-45.

[4] Ye Qiongwen, Nie Qiuyun. Empirical Analysis of the Affect of Ecommerce on Tertiary Industry [J]. Electronic Commerce, 2012(9):123-126.

[5] Lihao. Brief Analysis of the New Development of Modern Logistics in E-commerce Environment [J]. China Businesses and Trade, 2012(3): 67-69.

[6] Li Teijun. China's Industrial Structure in the New Century [M] Beijing: Economy \& Management Publishing House, 2014, 56-78.

[7] Du Chuanczhong, Ma Wuqiang. The Informatization and the Leaping Upgrading of China's Industrial Structure [J]. Shandong Social Science, 2014, 12(6): 23-33.

[8] Jiangbin. Introduction to International Regional Industrial Structure [M]. Shanghai: Shanghai People's Publishing House, 2011, 100129.

[9] Shilei. Cause and Transformation of China's Industrial Structure [M].Shanghai: Fudan University Press, 2011, 16-23.

[10] Chen Xiuqi. Logistics Management of Electronic Commerce [M] Beijing: Publishing House of Electronics Industry, 2011, 18-34

[11] Shi Zhongliang. Industrial Economics [M]. Beijing: Economic \& Management Publishing House, 2010, 44-49.

[12] Yu Chunhui. Industrial Economics Text and Case [M]. Beijing: China Machine Press, 2012, 77-90.

[13] Li Xianpei. China's Industrial Policies in the Early 21 st Century [M]. Beijing: Beijing: China Machine Press, 2014, 78-88.

[14] Liuwei. Research on Industrial Structure in Industrialization Process [M]. Beijing: China Renmin University Press, 2013, 28-33.

[15] Amin W. Mugera. Managing Human Resources On Six. Dairy Farms In Michigan.A Resource-Based Perspective [D]. Michigan State University, 2014

[16] Wilson J. D. A voluntary brain-drain tax [J]. Journal of Public Economics, 2011,92: 2385-2391 